Additional advantages to this more functional procedure necessarily follow. Since counsel no longer would have the opportunity to influence the jury with their personality, much of the incentive for detailed inquiry would be lost. Because each juryman would be subjected to only one examination, and that a more limited one, a more rapid and less expensive impanelment process would result..$^{30}$ Finally, the standardization and simplification of impanelment procedure would tend to reduce the number of appeals. While the court would still have some areas of discretion, there would be far fewer technicalities to serve as the subject of dispute.

\title{
AMENDMENT OF VERDICT IN CRIMINAL CASES AFTER THE JURY HAS BEEN DISCHARGED;
}

Is order that a criminal defendant may have a fair trial the jury must be impartial when impanelled and remain so until after it has announced its verdict and is discharged. Accordingly courts have developed rules designed to insure the selection of an unbiased body and to prevent outside influences from prejudicing a jury during trial. ${ }^{1}$ Moreover, any verdict rendered by a jury which is shown to have had important prejudicial contacts is invalid."

One stanchion in this framework of safeguards is the general rule that a discharged jury cannot be recalled to amend or alter its work. ${ }^{3}$ Since the purpose behind this rule is to prevent amendment of the verdict in response

30. See Atkinson, The Voir Dire Examination of Jurors in Fastsas, 1 J.B.A. Knit. 125, 134-5 (1932), and Potts, Desirability of the Federal System for Selcetion of Jorry 2-3, IDAEO S.B. 58, 62 (1926).

The excessive amounts of time and money spent in permitting attorneys to cxamine jurors have frequently been targets for the attacks of those advocating court-conducted voir dires. Athinson, supra, at 128; MrcCormich, Functions of Judge and Coussel is the Examination of Jurors, 22 J. Axr. INST. CRIMr. L. \& CrminoLcoy 734, 735 (1932) ; Mfoore, The Voir Dire Examination of $J_{\text {urors, }} I I, 17$ GEo. L.J. 13, 37 (1928). An extreme illustration of this delay and cost was the trial of a labor union slugger where the selection of the jury took nine and a half weeks. Ten thousand veniremen were summoncd, five thoucand talesmen were examined, and the cost to the state was estimated in the vicinity of forty or fifty thousand dollars. See Wilovgray, Principles of Jubicral Adsumistratro: 510 (1929).

* Commonwealth v. Johnson, $359 \mathrm{~Pa} .287,59$ A.2d $12 S$ (1918).

1. E.g., Peiffer v. Commonwealth, $15 \mathrm{~Pa} .46 \mathrm{~S}$ (1851) (jurors not allowed to separate in capital case) ; Commonwealth v. Deutsch, $72 \mathrm{~Pa}$. Super. 298 (1919) (jurors cannot read newspapers which would prejudice them); State v. Perry, 121 N.C. $\$ 33$ (1\$97) (jury visiting scene of crime made inquiry with regard to a material matter from a passerby). See generally, 1 HYATT, TrIats $\$ \$ 926-71$ (1924).

2. Mattox v. United States, 146 U.S. 140 (1892) (reading newspapers). Sce HYATT, TrIAIS $\$ \$ 922,924$ (1924).

3. Sargent v. State, 11 Ohio 472 (1S42); 1 HYatr, TruLs $\$ \$ 33$ (1924). 
to outside pressure or prejudice, ${ }^{4}$ its application seems appropriate only where the jury might have been so influenced. Where merely formal alterations are required and the jury's original intent is in all respects clear, amendments should be allowed regardless of whether the jury has been subjected to outside pressures. On the other hand, if the verdict cannot support a judgment because it has failed to indicate a complete disposition of the case, a jury which has separated should be allowed to amend only where it could not in any way have been prejudiced in the interim. If they can have been prejudiced and the verdict has such a defect, the result should be a mistrial. ${ }^{5}$

A fortiori, amendment should never be allowed where a jury which has rendered a verdict technically valid and clear on its face returns after it has been discharged and exposed to possible prejudice to claim that it intended a different result. Such was the situation in Commonwealth v. Johnson. ${ }^{\circ}$ When the court crier asked, "do you find Lee Ivory Johnson . . . charged with murder, guilty or not guilty?" the jury foreman replied, "not guilty." The jury was not polled, allegedly because the District Attorney was "shocked into somnolence by the apparent miscarriage of justice." 7 But the court crier read back the verdict as returned, and the judge expressed his surprise at the outcome. ${ }^{8}$ Nevertheless, no juror protesting, the jury was then discharged. It was not until after most of the jury had left the courtroom that a few returned to protest that the verdict was incomplete and unintended. The next day the jury was recalled, and it returned a unanimous verdict of "not guilty of murder but guilty of voluntary manslaughter," and sentence was imposed accordingly.

The Supreme Court of Pennsylvania vacated this sentence on the ground that the jury could not be reassembled after discharge to amend its verdict. ${ }^{9}$ Looking to the policy of eliminating possible prejudice which lies behind

4. "... [I]n no case can [the court] be permitted to recall a jury, to alter, or amend, their verdict, after it has been received, and the jury discharged. This would jeopardize the jealous guards, with which the law has surrounded jurors, to insure the pure administration of justice, and to protect the citizen ... no rule tending to insure the .. . purity of jurors, has, in the slightest degree, been abandoned or impaired." Sargent v. State, 11 Ohio 472,474 (1842).

5. People v. Lee Yune Chong, 94 Cal. 379, 29 Pac. 776 (1892) (jury failed to state degree of crime).

6. $359 \mathrm{~Pa} .287,59$ A.2d 128 (1948).

7. Brief for Appellees, p. 9, Commonwealth v. Johnson, note 6 supra.

8. The trial judge stated that, in view of the strong case presented against the defendant, he was satisfied "that the jury made a mistake." Commonwealth v. Johnson, 359 Pa. 287, 289, 59 A.2d 128, 129 (1948).

9. The appellate court was also worried about the abuses to which recall after discharge might lead. "If this practice were judicially sanctioned, a jury might acquit a defendant of a crime and then a day, a week or a month later reassemble and declare that the verdict was a mistake, that they intended to find the defendant guilty and would then proceed to do so. ... [Such a practice] is the antithesis of due process of law." I $d$. at 294,59 A.2d at 131. 
the rule against recall, this result seems appropriate: a jury which had dispersed and gone back to its work-a-day pursuits had returned to the court room to substantially amend a verdict. The risk that the amended verdict might have been affected by outside persuasion seems sufficiently great to justify application of the rule despite the resulting acquittal of one whom the jury had apparently intended to find guilty. ${ }^{10}$

But where amendment has served to correct a merely technical deficiency, courts have generally found the rule against recall of a discharged jury to be inapplicable. ${ }^{11}$ There is a sound rationale for permitting such amendments; since the intent of the jury nas clear before discharge, recall to correct errors in form is in no way unfair to the defendant. ${ }^{12}$ Thus amended verdicts have

10. However, after reversal in this case, it was still possible to try the defendant for involuntary manslaughter. Defendant demurred to the evidence offered by the state on the grounds that he could not be tried on an involuntary manslaughter charge when the Commonwealth had already established in the first trial that the crime vas viluntary and intentional. The judge overruled the demurrer, and the defendant sas found guilty. He was sentenced to two years in prison.

There have been other cases where refusal to permit amendment resulted in asquittal or a less severe verdict. Sec, e.g., Allison v. State, 143 Tex. Cr. R. 4, 156 S.W.2d 527 (1941) (jury recalled and amended verdict in accordance with its intention to recommend that sentence be not suspended rather than that it be suspended; on arpeal trial court ordered to enter judgment on the original verdict) ; Sargent v. State, 11 Ohio 472 (1842) (jury discharged after rendering verdict of guilty on first count of indictment but not specifying as to second count; held error for court to enter judgment of guilty on serond count after reassembling jury and ascertaining that they so intended).

11. Cunningham v. State, 14 Ala. App. 1, S, 69 So. 982,985 (1915) (verdist corrceted to include place of punishment which is, however, fised by law upon conviction); Layman v. State, 126 Tex. Cr. R. 533, 534, 73 S.WV.2d 97, 98 (1934) (jury failed to spacify count of the indictment on which they relied where only one count submitted to them in court's charge).

Sometimes, but never in a capital case, the jury is permitted to deliver a sealed verdict and separate until formal reopening of court. At that time they reconvene and give the verdict orally in the presence of the defendant and are polled if either party so requerts. As the sealed verdict is not recorded, the jury can vary from it upon delivering the oral verdict in court. Hyatr, Trials $\$ \$ \$ 17,827$ (1924). Here, too, corrections as to form are usually permitted. Steudle v. Territory, 19 Okla. 492, 91 Pac. 1024 (1907) (verdict found all the defendants guilty except one who had been previously dismissed, but failed to specify their names); Rhodes v. State, 68 OHa. Cr. R. 1, 49 P.2d 225 (1935) (jury mistakenly used word "money" in verdict instead of "property"); but if the change affects the substance of the rerdict, a mistrial usually results. Commonwealth v. Lemley, $158 \mathrm{~Pa}$. Super. 125, 44 A.2d 317 (1945) (jurors changed their minds); sce Pcople v. Duffek, 163 Mích. 196, 205, 128 N.W. 245, 248 (1910); but cf. Jacl:son v. State, 45 Gz. 198 (1872) (actions of defense counsel validated judge's reeall of jury which hod not found as to the degree of manslaughter). And to send a jury out for further deliberations, if the result will affect the substance of the verdict, is reversible error. Wells $\mathrm{v}$. Stzte, 116 Ga. 87, 42 S.E. 390 (1902); Petitti v. State, 2 Ohla. Cr. R. 131, 100 Pac. 1122 (1909).

12. See Cunningham v. State, 14 Ala. App. 1, \&, 69 So. 982, 985 (1915); Taggart v. Commonwealth, 104 Ky. 301, 305, 46 S.W. 674, 675 (189S). 
been permitted when the jury misspelled the name of the defendant ${ }^{13}$ or failed to specify the count of the indictment on which they relied where only one count was submitted to them in the court's charge. ${ }^{14}$ Analogous amendments are those necessary to correct defects in the manner of rendering the verdict. Here, too, recall has been allowed to correct a deficiency caused by delivery of the verdict when the defendant was not in court, ${ }^{16}$ or when the jury has not been counted to ascertain if all were present. ${ }^{16}$

At times, however, courts have blindly applied the rule against recall and invalidated verdicts regardless of whether the jury was, or could possibly, have been prejudiced. Some courts set recordation of a verdict as an arbitrary time after which not even a formal amendment will be permitted. ${ }^{17}$ But recordation seems an unduly strict criterion for insuring that the jury has not been open to prejudice, for the verdict is recorded by the clerk when rendered orally and there may be a substantial lapse of time before the jury separates. ${ }^{18}$

More often, courts have indicated, by allowing amendments where the jury is still present ${ }^{19}$ and disallowing them where it has left the presence of the court, ${ }^{20}$ that presence is a rule of thumb test for determining a jury's exposure to prejudice. But "presence," too, is an illogical criterion since the mere fact that the jury has never left the courtroom does not insure that it has not been subjected to prejudicial influences. For example, a hostile courtroom crowd may exert more than a modicum of pressure on a jury that has failed to assuage its fancy. Or a judge with strong views on the guilt or innocence of the defendant might be influential in causing a jury to realize

13. E.g., Commonwealth v. Breyessee, $160 \mathrm{~Pa} .451,28$ At1. 824 (1894).

14. E.q., Layman v. State, 126 Tex. Cr. R. 533, 73 S.W.2d 97 (1934).

15. Summers v. U.S., 11 F.2d 583 (1926), cert. denied, 271 U.S. 681 (1926); Brister v. State, 26 Ala. 107 (1855).

16. Mitchell v. State, $22 \mathrm{Ga} .211$ (1857).

17. Ford v. State, 12 Md. 514 (1858). See Henner v. State, 104 Arli 606, 615, 150 S.W. 146 (1912).

18. The only argument for permitting amendments as to form after recordation lies in the abstract concept that a jury, once it has issued a verdict, ceases to exist and cannot be revived. See Perryman v. State, 102 Tex. Cr. R. 531, 533, 278 S.W. 439, 440 (1925) (". . . before the jurors were reassembled their identity as an organized body had ceased, and the verdict [as amended] is but the act of a collection of individuals who hatd previously been members of the jury.").

19. Summers v. U.S., 11 F.2d 583 (1926), cert. denied, 271 U.S. 681 (1926) (jury still an undispersed unit within the control of the court); Cunningham v. State, 14 Ala. App. 1, 69 So. 982 (1915) (jury called back before leaving courtroom).

20. People v. Lee Yune Chong, 94 Cal. 379, 385, 29 Pac. 776, 778 (1892) ("A court would, no doubt, have the power to direct a jury to correct an informal verdict, although the mistake had not been discovered until after the verdict had been entered upon the minutes, 'while the jury are before it and under its control.'"). Sec Melton v. Commonwealth, 132 Va. 703, 712, 111 S.E. 291, 294 (1922) ("So long as the whole jury are in the actual and visible presence of the court, and under its control, an inadvertent announcement of discharge may be recalled . . . but not thereafter.") 
that it had "made a mistake." Furthermore, even though a jury has separated and left the presence of the court, it is conceivable that the members might be reassembled before any of them has been exposed to a prejudicial influence. ${ }^{21}$

In view of the danger of erroneous verdicts, plus the difficulty of their correction, two preventive measures seem in order. Polling the jury should be standard practice instead of depending on request by the parties."2 In addition, the recorded verdict should be carefully reviewed by the court to insure technical correctness before the jury separates. But erroneous verdicts resulting from unintentional slip-ups will still occur on occasion, and when they are discovered, the problem of amendment emerges. In these situations, blanket application of the rule against recall seems far less desirable than application of the policy behind the rule to each situation. No reason is apparent for denying any correction as to form or even as to substance where it conclusively appears that the jury, although discharged, has not been exposed to prejudice.

Edgar L. SANFord, Jr.í

21. See, e.g. Mills v. Commonwealth, 7 Leigh. 751 (Va. 1836) (only one juror leit the courthouse and he went forty or fifty yards in the company of a deputy sherifi).

22. See HYATT, TRIALS $\$ 755$ (1924).

$\doteqdot$ Member of the second-year class, Yale Law School. 